\title{
The Dardanelles Campaign and the Contending Strategies for War
}

\author{
Sevtap Demirci \\ Boğaziçi University, Istanbul, Turkey
}

\begin{abstract}
The idea that WWI was a global conflict is generally accepted by the scholarly community. The Great War, as it is otherwise called, deserves to be remembered not only by the European nations but also by the rest of the world countries whose destinies were shaped by it or because of it. It would not be wrong to suggest that the WWI, as far as the Ottomans were concerned, was a history of European armies in non-European military stages. The historiography of World War I is often limited to English sources seemingly due to the negligence of Ottoman sources, but most probably caused by the language barrier[s] and/or the Eurocentric approach to history. Or in Erikson's words, the "resultant historiography tends to tell the story from an overwhelmingly European perspective, which in many ways reflected what the European Powers perceived rather than what actually occurred" (Erickson, 2008, p. 10). It is my opinion that the wider use of Ottoman archives and Turkish narratives would provide a more balanced analysis and that a holistic understanding of the events that unfolded requires special attention to the Ottoman perspective. This paper suggests an analysis of the Dardanelles conflict from a strategic perspective, with special reference to British and Ottoman policies and their part played in the transition from peace to war; the ensuing political turmoil that led to an open conflict between Britain and the Ottoman Empire.
\end{abstract}

Keywords: Ottoman Empire, Great War, Gallipoli campaign, Dardanelles, Young Turks, Allies

\section{Historical Background}

To begin with, I would like to point out a commonly misused terminology in the literature. Despite the fact that the Ottoman Empire was multinational and multiethnic, Europeans insistently referred to them collectively as "the Turks" and "the Turkish Empire" despite the fact that the correct nomenclature for the Empire and its people was "Ottoman". Throughout the presentation I will use "Ottoman" to avoid a homogenised orientalist approach.

The Eastern Question, an expression used to denote the plethora of problems created by the lingering decline of the Ottoman Empire, had been the main item on the agenda of international relations in Europe since the mid-19th century. At the core of the issue was the question of what would and should become of the ailing Ottoman Empire. The more the economic and strategic interests of the great powers in the Empire grew, the more firmly the Eastern Question became rooted in Europe's diplomatic and political relations. The Ottoman Empire, a vast entity over the Near and Middle East, and from the Balkans in the West to North Africa and the Arabian peninsula, was proxy to this rivalry.

Sevtap Demirci, Professor, Ph.D., Atatürk Institute for Modern Turkish History, Boğaziçi University. 
The great powers of Europe believed that the First World War would bring the Eastern Question to an end-a conviction that was proven to be correct. As far as the Ottoman Empire was concerned, the Great War of 1914-1918 was but the culmination of this long process of dissolution. As for the Europeans it was "one of an escalating crises between the great powers of Europe, the growth in Russian strength at the expense of the declining Austria Hungarian Empire and of Germany's determination to expand its power in the face of the Triple Entente" (Gilbert, 2000, p. 16) which led to the Ottoman loss of a great extent of territory. When the war ended in 1918, there was practically no Ottoman Empire remaining. The Sevres peace treaty, dictated by the Allies (August 10, 1920) following the Mudros Armistice October 30, 1918, territorially carved up "the sick man of Europe", thus bringing the Eastern Question to its end (Demirci, 2014, pp. 181-196). This begs the question how had a 600-year-old powerful Empire come to be a part of a partitioning plan by the great powers of Europe?

Starting from the second half of the 16th century attempts were made to protect the Ottoman Empire's Christian subjects. They were initiated by France and followed by Russia, the British Empire and the United States. A system of foreign missionary schools was established throughout the Empire under the pretext of defending and educating the diverse minority communities. Later the French Revolution of 1789 had detrimental effects on the Empire encouraging revolutionary ideas and activities among the non-muslim subjects eventually leading to independence. By the end of the 17th century, the Ottoman Empire, from being the most influential power in world politics, had lost a large part of its power and the military weakness was accompanied by a permanent fiscal crisis. The Empire labeled "the Sick Man of Europe" since 1844, had entered a long process of dissolution.

A series of ill-fated events began shortly after the Young Turk administration came to power in 1908 and the dismemberment of the Ottoman Empire gained momentum. In the same year Bulgaria declared its independence, Austria-Hungary annexed Bosnia-Herzegovina, and Crete proclaimed its union with Greece. In 1911 Italians invaded Tripoli and Cyrenaica. At the end of the war in 1912 the Ottomans had lost both Libya and the Dodecanese islands. But more was yet to come. In the same year, after having formed an alliance, the Balkan states (Serbia, Bulgaria, Greece and Montenegro) attacked the Ottoman provinces in the Balkans forcing the Empire to give up these provinces as well as the Aegean Islands. The Empire was in danger of losing Istanbul but the bitter dispute - that came to be known as the second Balkan War-broke out amongst the belligerent states as to how to share the spoils of war, an ambivalence which in turn gave the Ottomans the chance to gain control over their capital city and recapture some of their lost territories. As a result, not only did the Empire lose all its European territories but it also had to deal with the influx of millions of Muslim refugees without a chance to recover before WWI broke out.

\section{Choosing Sides}

As Shaw (2006) had once asked: "Why did the Ottomans enter a war against states that were far more formidable in size, population and financial and military strength?” (p. 2; Reynolds, 2011, pp. 108-113). My answer in one sentence is: They had no other option. So, why was this the case? An Ottoman perspective offers various explanations.

Firstly, Ottomans, in light of the above mentioned threatening circumstances, rather than fighting against the powerful Allies, were in fact in search of alignment with them. Apart from their objections to the Allies' policies and plans for partition of the Empire, the Young Turks turned to Britain and in January 1914, an 
alliance was proposed to the Entente "if for no other reason than to get the British and the French to restrain the ambitions for Ottoman territory of their Russian ally"1 (Shaw, 2006, pp. 2-3). It was turned down based on the assumption that the Ottoman Empire was falling apart and would end up being shared amongst the Allies anyway. They were not interested in the Ottoman pressure for concessions such as "a promise to end the capitulations, certain territorial clauses in the Caucasus and the Aegean Islands and a war indemnity to which the Germans agreed" (Erickson, 2008, p. 21), so the Ottomans had no option but to side with the Central Powers.

Secondly, of utmost importance is the fact that the Young Turks were not a stable, cohesive governing body. As much as entailing pro German tendencies within it, some favoured the Allies but the conjecture worked in favour of the Germans, which will be explained below.

Thirdly, the promise issued by the Allies that Ottoman territorial integrity would be protected if the Ottomans remained neutral in the war, fell on deaf ears. The Young Turk government expressed their distrust calling it "an empty one, a diplomatic hoodwink intended to buy time and to prevent the conflict from spreading" (Aksakal, 2008, p. 4). The Grand Vizier Said Halim Pasa reiterated the governments view by stating that the Empire "knew that to enter into relations with Great Britain, France and Russia would have been a harmful factor in respect to the country's interest" (Aksakal, 2008, p. 193).

Additionally, the unfortunate British decision to confiscate the battleships Reşadiye and Sultan Osman which were commissioned by the Ottoman Empire and being built in the British shipyards contributed to the Ottoman's decision to side with Germany. The decision taken by the First Lord of the Admiralty, Sir Winston Churchill may have had, to quote James (1965), "a strong military justification but the manner in which it was carried out was inept” (p. 4; Beşikçi, 2014, pp. 116-169), as the Ottoman officials were on their way to Britain to get the ships. However, the unfortunate decision was taken five days before the Ottoman-German alliance of August 2, 1914 (Shaw, 2006, p. 65). The cost of these two battleships was pre-paid by public subscription and so the appropriations caused great resentment within Ottoman public.

Fourthly, the Ottomans believed that Germany was a strong economic, military and political power and would emerge victorious from the war. Hence, they joined the war siding with Germany as they hoped to recover the territories they had lost to Europeans prior to the Great War. The War Minister Enver Pasha's proposal for a close relationship was overturned by the German ambassador to Istanbul Hans von Wangenheim but two days later after the Pasha's overture, the Keiser overruled his ambassador. "At the present moment", he remarked (the Austrian ultimatum to Serbia had been delivered in the previous evening), "Ottoman interest in a connection with the Triple Alliance should be taken advantage of for reasons of expediency" (Trumpener, 1968, p. 15$)^{2}$.

\footnotetext{
1 To reinforce its effort, the Ottoman government provided Britain with new concessions to construct railroads in Anatolia, increased its purchase of arms and ammunitions from British factories, and submitted new orders for the construction of large warships in British shipyards. The negotiations also accepted British spheres of influence in the Gulf and South Arabia thus marking Ottoman recognition of the dominant position Britain had already secured in these Ottoman possessions during the previous half century. British companies were given new concessions to operate river transport in Shatt ul-Arab and on the Tigris and Euphrates rivers in Ottoman Iraq. British companies were given concessions to build harbours and ports along the Black Sea cost at Trabzon and Samsun. British naval experts were to continue as advisors in the modernisation of the Ottoman navy and Ottoman shipyards. However they refused to secure an alliance with the Ottomans with the belief that the Empire would in any case break up and they would take their share.

${ }^{2}$ Germans believed that the Ottoman declaration of Jihad would incite a riot among the Muslim population of Britain and France and ease the position of Central Powers.
} 
Another reason why the Ottomans decided to join the war on the German side was the already existent military relations between the Ottoman Empire and Germany that had been maturing since the second half of the 19th century. German military advisers, engaged in the modernisation and reform of the Ottoman Army in the pre-war period, a process seen by some foreign observers as the "Prussianisation of the Sultan's army" (Trumpener, 1975, pp. 30-44). Most of the senior officers in the Ottoman army at the time of war were German. Furthermore the Ottoman army's senior officers were mainly German.

Alongside military and political cooperation, economic and commercial relations had also been intensifying since the 1880s. German economic activity in the Ottoman Empire prior to the war was characterized by heavy investments in areas of "municipal transportation, electric utilities, agriculture and mining, and by a steadily mounting volume of trade" between the two countries. Most of the "central military establishments, including the Ministry of War's departments of operations, intelligence, railways, supply, munitions and fortresses" (Trumpener, 1968, p. 15; Fewster, V. Başarın, \& H. H. Başarın, 2003, pp. 38-39) were run by the Germans. Notably, Germans also had heavily invested in the Ottoman railways (The Berlin-Baghdad Railway).

As Ericsson rightly put it, when the war broke out all of the European powers had definite war objectives except the Ottomans. That is to say, the British aimed to secure the road to India and the Suez Canal, the French wanted "Alsace Lorraine", the Russians ambitions were to seize the straits and Istanbul, and the Austrians desired to control Serbian hegemony. The Ottoman Empire, in the wake of its Balkan defeat, had no clear war goals in the summer of 1914, "neither did it have any sort of offensive mobilisation scheme or war plan" (Erickson, 2008, p. 20). Considering the close relations with Germany in almost every sphere and the Allies aloofness to the Ottoman overtures, the Ottomans were left with no choice but to side with the Germans. This was a great relief for the Germans who feared an Ottoman alignment with the Allies would bring an end to the substantial German economic and financial penetration of the Ottoman Empire.

\section{Ottoman Entry Into the Great War 1914-1918}

The Ottoman Empire entered the war on the side of Germany and Austria-Hungary on October 29, 1914. In Aksal's words: "the Ottomans only entered the war after three months of foot-dragging, deception and protracted negotiations" with Berlin. Once they secured the Alliance with Germany August 2, 1914, they focused their energies on postponing any military engagement. They repeatedly insisted on "the necessity of an alliance with Bulgaria and for more time to complete their mobilisation efforts" (Aksakal, 2008, p.194).

The German plan was to drag the Ottomans into war as soon as possible by opening a new front in the east thus weakening the Allies in the eastern fronts thus contributing to their defeat in the western front. Wangenheim convinced the German Foreign Office:

In case we do not come to an agreement with the Turks at the present moment, we shall, in my opinion, drive them into the arms of our opponents. I think that under the present circumstances we should agree to a term of duration for the alliance until 1918 - to the end of the Liman mission - but in this case, we should absolutely draw Austria-Hungary in, too, as a second power in the compact" (Aksakal, 2008, p. 69).

According to the Germans, Ottomans were minor players and had the functional role of keeping the Allies busy and extending the war. "The Turks were not able to win the war for Germany they were able to weaken significantly or divert the war efforts of Germany's main opponents" (Erickson, 2008, p. 30). Interestingly, 
Enver Pasha's intentions stated in a letter to his General Staff in the final month of fighting overlapped with the German view,

The purpose of our entry into the war on the side of Germany, Austria-Hungary, and Bulgaria was to engage as many troops as possible and to keep these away from the European theatre, where the outcome of the war would be decided. The Ottoman army and Navy fully pursued this objective without interruption. And they have until now completely fulfilled this task on all fronts despite many sacrifices. (Aksakal, 2008, p. 188)

The entry of the Ottoman Empire into the war was a victory for the Germans. This move opened up three land fronts with the Entente, as well as forcing the Royal Navy to conduct a blockade in three seas.

The World War I broke out on August 1, 1914 and the next day the Alliance between Ottoman Empire and Germany was signed by German ambassador to the Porte Baron Hans von Wangenheim and by Ottoman Grand Vizier Sait Halim Pasha in Tarabya. Wangenheim and Enver Pasha's famous secret treaty of Alliance was not a formal alliance. The parties pledged to support each other and, more importantly from the Ottoman perspective the agreement was "defensive in nature" (Erickson, 2008, p. 20). The treaty itself did not bring the Turks into the war but aligned them with the Germans and alienated them from the British and French.

The first day of the war, August 1st, witnessed one of the most famous episodes of the war: the Flight of the Goeben and Breslau (Ulrichsen, 2014, p. 77) ${ }^{3}$. The two German warships, trapped in Mediterranean, were being pursued by the British Mediterranean fleet. These ships were allowed, in violation of naval warfare regulations, to take refuge in the straits. The rules of engagement made clear that they either had to be sent back or seized. What happened instead was the adoption of these two vessels by the Ottomans - who named them immediately as Yavuz and the Midilli-and the switch in dress code of German crew into Ottoman uniforms and fezzez. This was a fait accompli the Allies had not prepared for. However, tension was accumulating and within roughly two months, on September 27, it burst into open hostilities.

The British squadron off the entrance of the Dardanelles ordered a Turkish torpedo boat to turn back. There was no justification whatsoever for this high-handed action and it gave the Germans the opportunity they needed. Germans persuaded the Ottomans to close the Dardanelles, "lighthouses were extinguished mines sown and warning notices appeared on the cliffs" (James, 1965, p. 21) ${ }^{4}$. The Allies responded in a fury. The British reaction, initiated by the First Lord of Admiralty Winston Churchill, was to catch and sink the ships while they were in the Marmara Sea but he was stopped by his colleagues - the Secretary of State for War, Kitchener and prime minister, Asquith—whose priority lied in seizing Gallipoli.

Things soon got out of hand when the German/Ottoman warships, in violation of Sait Halim's directives and under the command of German admiral Souchon entered the Black Sea, attacked Russian ships and

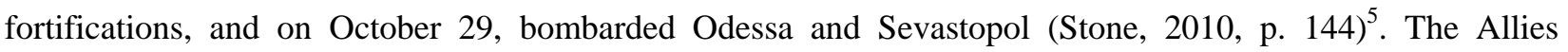
believed that the attack was ordered from Berlin and this was interpreted as the Ottoman government being completely under German control. They assured that the Ottomans had allied with the Central Powers. This was also evident in the Tsar's remark,

\footnotetext{
3 Başbakanlık Devlet Arşivleri Genel Müdürlüğü, Osmanlı Arşivi Daire Başkanlığı. Osmanlı Belgelerinde Çanakkale Muharebeleri I. No. 71; No.1/p. 3; No. 2/ p. 5. Ankara, 2005.

4 Başbakanlık Devlet Arşivleri Genel Müdürlüğü, Osmanlı Arşivi Daire Başkanlığı., Osmanlı Belgelerinde Çanakale Muharebeleri. I, No.1/p. 3. Ankara, 2005.

5 The Grand Vizier Said Halim went to Wangenheim stating that he had known nothing about the attack, that neither the Ottoman government nor himself was in any way responsible for it, that it was the work only of a few rogue ministers.
} 
Under German command the Turkish fleet has had the treacherous effort to try to attack our Black Sea. We share with all the peoples of Russia the unshakable conviction that the rush intervention of Turkey will only hasten that country's downfall and open Russia's path towards the solution of the historic problem which our ancestors have bequeathed to us on the shores of the Black Sea. (Shaw, 2006, p. 734)

The Ottomans offered compensation but were rejected by the Russians. On November 2 Russia declared war on the Ottomans alongside the British and the French who followed suit on the next day. "From the moment the Ottoman Empire entered the war with her naval bombardment of Odessa on 29 October 1914, as an ally of Germany, the defeat of Empire became a war aim of the Entente Powers" (Gilbert, 2000, p. xiii). Within two weeks, on November 11, the Sultan in turn declared war and called for Jihad.

Hostilities began on October 31st, two days later after the naval bombardment of the Russian ports by the Ottoman/German warships. The British Admiralty gave a 12-hour ultimatum to the Ottomans-an opportunity to hand the German soldiers and the crew over, otherwise a war would be declared instantly. Once the time limit had been reached the British Admiralty ordered Admiral Carden, Commander of the Dardanelles Patrol, to attack the Dardanelles forts in addition to attacking the port of Izmir, accusing an Ottoman ship of lying mines (Shaw, 2006, p. 737). Two days later, on November 3 the Seddulbahir and Kumkale (on the Gallipoli Peninsula) were bombarded. On December 13 the old Ottoman battleship Mesudiye sunk. The tension was running high.

\section{Gallipoli Campaign}

It is ironic that the campaign is called by the name Gallipoli which derives from Greek for "nice town". The Turks adopted a similar name for it — "Gelibolu" - whilst the name for the campaign as a whole is referred as Çanakkale, which corresponds to Western discourses of the Dardanelles. The Gallipoli campaign being a military campaign and an historical event is now a century old and contested ground. The experience of Gallipoli will be assessed in the light of recently available documentation and an ongoing process of further understanding,

\section{From the Allies' Point of View}

Once a deadlock was reached on the western front in late 1914, the Allies, particularly Britain, sought an "alternative theatre of operations which prosecute the war" (Prior, 2010, p. 241). The First Lord of the Admiralty, Winston Churchill, believed that to "use the Greek army to seize the Gallipoli peninsula" would "open the Dardanelles; admitting the Anglo Greek fleet to the sea of Marmara, whence the Turco-German ships can be fought and sunk, and where in combination with the Russian Black Sea Fleet and Russian military Forces, the whole situation can be dominated" (Gilbert, 2000, p. xiv; Shaw, 2006, Vol.II, p. 1507; Gilbert, 2004, pp. 15-16). Lloyd George shared this same view: "The Dardanelles appeared to be the most suitable objective, as an attack here could be made in co-operation with the Fleet. If successful, it would re-establish communication with Russia: settle the Near Eastern question, draw in Greece and perhaps, Bulgaria and Romania, and release wheat and shipping now locked up in the Black Sea" (Prior, 2010, p. 17).

The Entente's campaign against the Dardanelles is usually described by historians as having been the idea of Winston Churchill and his First Sea Lord, John Fisher, "for the purpose of opening the straits in order to send supplies to their Russian ally so that it could pressure the Central Powers on the eastern front and to capture Istanbul... and in the process knock the Ottoman Empire out of the war, depriving the Germans and Austria-Hungarians of what they had come to consider a vital ally" (Shaw, 2006, Vol. II, p. 1497; Coates, 2001, 
pp. 111-211). Archival material reveals that Churchill responded to "a Russian plea in early December 1914 for a British attack to divert the Ottomans from Enver Pasha's campaign into the Caucasus, which they had very much feared would, not only conquer the area, but also break into Central Asia because the bulk of Russia's Caucasus army had been shifted to meet what it had earlier thought to be more serious threat of German and Austria-Hungarian attacks in Poland and Galicia" (Shaw, 2006, Vol. II, p. 1497).

Early this week position of Russians in the Caucasus gave cause for great anxiety. Turks having commenced enveloping movement seriously threatened Russian forces. Commander-in-Chief of army in the Caucasus (Vorontzov-Dashkov) pressed most urgently for reinforcements... Grand Duke asked if it would be possible for Lord Kitchner to arrange for a demonstration of some kind against the Turks elsewhere, either naval or military, and to spread reports which would cause Turks, who he says are very liable to go off at a tangent, to withdraw some of the forces now acting against Russia in the Caucasus, and thus ease the position of Russia. (Shaw, pp. 1497-1498, Sir Edward Grey to Churchill, Jan 1, 1915)

By January 19, British war Cabinet, having been convinced by Churchill and the Secretary of State for War, Kitchener took the decision that the way to divert the Ottomans was to bombard the Dardanelles.

The Admiralty has considered with deep attention the request conveyed through Lord Kitchener from your Imperial Highness for naval action against Turkey to relieve pressure in the Caucasus... It has therefore been determined to attempt to force the passage of the Dardanelles by naval force. The method chosen is the systematic and deliberate reduction of the forts by the long range fire of the 15 inch guns of the "Queen Elizabeth" followed up by direct attacks by old battleships. It is expected that the operation will take three or four weeks...

This action was welcomed by Russia. In the opinion of the Tsar "any military action against Turkey of the kind contemplated would be bound to have important results for the Allied course. It could not be hoped to crush Turkey in the Caucasus... but a successful attack against Turkey would react on the principal enemy (German) line; it would paralyze Turkey; and would infallibly be a deciding factor in determining the attitude of neutral states in the Balkans" (Shaw, 2006, Vol. II, p. 1501; Kearsey, 2006, p. 5; Rogen, 2015, pp. 132-133).

Britain was now in a position far from its century old traditional policy of maintaining the integrity of the Ottoman Empire. By offering Istanbul and the straits to Russia in return for its remaining in the war as a Triple Entente, and its official recognition of the British annexation of Ottoman Egypt (previously occupied with Ottoman suzerainty retained), Russia approved of the British and French plans to divide the entire Middle East among themselves as in the Sykes-Picot agreement (Shaw, 2006, Vol. II, p. 1515; Bartlett, 2007, pp.25-26).

Despite having been warned by the British intelligence officer Charles Callwell about the risk of a frontal naval bombardment of the Dardanelles, without a Cabinet decision or approval Churchill ordered the British Admiral commanding the Greek fleet, Sir Mark Kerr, to discuss the possibility of a joint attack.

The initial idea that the land forces would not be needed, or only be needed in an auxiliary role, would be abandoned due to the reservations of a number of Admiralty commanders, and the British Prime Minister Asquith. They agreed the necessity of the land troops to finish the job. The British fleet began bombarding the outer forts on the Dardanelles on 19 February $1915^{6}$. The Allies convinced that the Dardanelles would fall, Istanbul captured and the Ottomans forced out of the war within a very short period of time. Perhaps the most difficult task was to reconcile the opposing interests of the Greeks and Russians as to the straits and Istanbul, and keep them in the Entente. In renunciation of Greek aspirations as to Istanbul and the straits, a powerful

\footnotetext{
${ }^{6}$ Başbakanlık Devlet Arşivleri Genel Müdürlüğü, Osmanlı Arşivi Daire Başkanlı̆̆ı.Vol. I. No.71; No.34/p.36; No.8/p.10; No.14/p.10. Ankara, 2005.
} 
Greek state was envisaged in western Anatolia. Once this was resolved, Churchill proceeded with his plan and persisted in his attack by ignoring the advice of his intelligence officers and not taking seriously the strength of the Ottoman forts and minefields, believing in the superiority of the British naval position. Churchill expressed his conviction to his Foreign Secretary Sir Edward Grey in the following lines: "Should we get through Dardanelles, as is now likely, we cannot be content with anything less than the surrender of everything Turkish in Europe" (Shaw, 2006, p. 1531; Hartesveldt, 1997, pp. 4-5). The first task of Admiral Sackville-Carden was to destroy the "Turco-German fleet" after having broken into the Dardanelles and entered the Marmara Sea. Even the terms of the armistice, which would be imposed upon the Ottomans after the expected victory, were fixed.

\section{What was Happening on the Ottoman Front?}

The literature on the British and Anzac perspectives of the Gallipoli campaign is plentiful, but only a limited range of sources cover Ottoman experiences. Despite a few acknowledgements, western historiography shows "a dismal picture of the Ottoman position at war, in which Turkish successes are largely attributed to allied mistakes, the activities of German generals or inhospitable terrain and conditions" (Erickson, 2008, p. 10). The British saw the Ottoman army as one of "ill-commanded, ill-officered" and "in rags" (Erickson, 2008, p. 18). This was not the case at all.

The Ottomans had already heavily fortified the Dardanelles in anticipation of a naval attack during the First Balkan Wars in 1912. Due to the imminent threat of war, they were "improving the road network and the fortifications along the likely landing beaches, camouflaging troops and artillery batteries, putting barbed barbed-wire fences, raising the standards of existing hospital situation" (Erickson, 2008, p. 66-67; Shakland \& Hunter, 1964, p. 147 $)^{7}$. The mounting dissension regarding the naval and military plans for the attack on the Dardanelles gave the Ottomans considerable warnings and time to take counter measures reorganising the defense of the Peninsula. The Çanakkale Fortified Area Command was set up and fortified by men and equipment, and although not at the desired speed, the mobilization of the artillery corps, was completed at the straits. The Red Crescent organization established mobile clinics all over the Peninsula, groups of mobile howitzers were placed in position to bombard enemy ships, and anti-submarine nets were spread out in belts in the narrows.

Despite this preparation, archival material reveals that the Ottoman army in Gallipoli was in a disadvantageous position compared to Allies forces. It was lacking arms, ammunition and further resources such as "decent food, primitive sanitation, the corpses decaying in trenches, plagued by dysentery, enteric fever and lice, and ever present thirst". The cannons were outdated ammunition and other supplies were in short supply. However, with the help of the Turkish mine-layer, Nousret ${ }^{8}$ they did have very effective mine-laying strategy in place: The Allies were caught out because the main line of mines was laid parallel to the shore, and the British Navy was ambushed by their unusual positioning. Moreover, none of the German officers spoke Ottoman Turkish and they lacked familiarity with their organizational structure, and "all of them held the Turks in very low professional regard" (Erickson, 2008, p. 18; Kannengiesse Pasha, 1928, pp. 126-130). For all that the Turks were well aware they were fighting in defense of their native land against foreign aggression. If they

\footnotetext{
${ }^{7}$ Başbakanlık Devlet Arşivleri Genel Müdürlüğü., Osmanlı Belgelerinde Çanakkale Muharebeleri. Cilt I., p. 25. Ankara: Başbakanlık Basımevi, 2005.

${ }^{8}$ Birinci Dünya Harbinde Türk Harbi, Çanakkale Cephesi Harekatı. Vol.5/1. Ankara: Genelkurmay Basımevi, 1993.
} 
held Gallipoli, they could keep the straits and the road to Istanbul safe. Hence, for them this was not an ordinary battle- - It was a matter of life and death, essentially a struggle for survival.

\section{If We Go Back to the Battle}

On March 13, Kitchener clearly instructed Ian Hamilton, the General Officer Commanding-in-Chief, to unleash the Mediterranean Expeditionary Force, and an attack began immediately. However, by March 18, the Ottoman resistancee was far more powerful than the British had expected, and was able to stop the assault (Erdemir \& Güneş, 2014, pp. 31-33). The Queen Elisabeth and two other battleships had struck Ottoman mines and sunk. Hamilton informed the British War Cabinet that naval bombardment alone would not be sufficient to destroy the Ottoman defenses and major land forces were needed.

The Ottomans made preparations against the expected British forces return by patrolling, attacking warships and troopships, and transporting Ottoman military units and materials wherever needed. War Minister Enver Pasha had decided to bring all the units together under a new "Fifth Army" under General Otto Liman von Sanders's command, who was the head of German military mission and Commander of the Ottoman First Army of Istanbul. Sanders arrived at the Peninsula and was stationed in the Headquarters of the Third Army Corps under the command of Esad Pasha (Özdemir \& Mutaf, 2012, pp. 23-25; Ilgar \& Uğurlu, 2003, p. 56).

Liman von Sanders was not a capable field commander as portrayed in much of the European military and diplomatic literature. A younger colleague, General Hans von Seeckt, who served as Chief of Staff in the Turkish General Headquarters in 1917-1918, wrote of Liman's selection,

The choice of the Chief of the Military Mission could scarcely have fallen more unfortunately. Found in Germany unsuitable for the command of an Army Corps, he was supposed to take over the rebuilding of the whole Turkish army. One simply could not demonstrate indifference in worse terms: it was an admission that we had not understood the principle that, for the representation abroad of a strong nation, only the best would suffice. (Gilbert, 2000, p. 67)

Liman von Sanders followed the original plan that had been devised before his arrival and only engaged in organizational matters. He used reserves and replacement to fill in gaps in existing military units, improved roads and other means of communications between the various army units. Experienced and vigorous Turkish officers such as Chief of Staff Kazım Karabekir, Lieutenant Mustafa Kemal Atatürk, and Esad Pasha, and many others, fell under his command.

The British forces consisted mainly of Australian and New Zealand soldiers. In violation of the Greek neutrality, they were stationed at the Greek island Lesbos. Further four French battalions from Senegal and a small number of Indian regulars were expected on April 20 but were delayed due to bad weather. Between April and August 1915 both sides suffered heavy casualties. The British made one last move to attempt to destroy the Fifth Army by carrying-out a massive attack in August that year. This was probably the main turning point for the Ottomans at the Gallipoli fronts where Liman von Sanders' orders were challenged by M. Kemal, who did not agree with him with regards to the likely positioning of a British landing. Mustafa Kemal proved to be right as the British forces landed at the site which he had foreseen. By then M.K. had made a name for himself, aided further by his insightful decisions and performance of heroic leadership (Muhlman, 2006; Vaidis, 2005, p. 105; Bean, 1948, pp. 131-136; Pomiankowiski, 1990, p. 121; Hayhorntwaite, 1991; Sanders, 1999, pp. 111-112). He instructed his soldiers to resist even he had not been ordered to do so. It was in this critical battle that Mustafa Kemal issued his famous order to a group of soldiers who were about to abandon their trenches:

\footnotetext{
${ }^{9}$ Başbakanlık Devlet Arşivleri genel Müdürlüğü, Osmanlı Arşivi Daire Başkanlığı. Vo. II, No. 73, No.11, p.41. Ankara, 2005.
} 
"Stop! Why are you running away?

-Sir! The enemy

-One doesn't run away but fights

-We have no ammunition left

-You still have your bayonets. Fix them and lay down" and Mustafa Kemal later reported that this was "the split second in time that saved the whole defensive front from collapsing. The enemy was forced to lie down when the 57th Regiment came to dislodge them" (Prior, 2010, p. 21). The order that this regiment had received from M. Kemal was clear: "I do not expect you to attack, I order you to die! In time which passes until we die, our troops and commanders can take our place" (Erickson, 2008, pp. 75-76; Fewster, V. Başarın, \& H. H. Başarın, 2003, pp. 7-8). In the memory of the Turks, the 57th Infantry Regiment is still famous because none survived. After almost nine months of continuous fighting the British believed that the expedition had come to an end and made the decision to withdraw. Preparations for the withdrawal started in December 12 and were completed by January 9, 1916.

\section{Conclusion}

The First World War destroyed the existing international system and brought down three mighty empires namely Russian, Austria-Hungarian and Ottoman. Ottoman political leadership concluded that it was imperative to join the war on the side of the Central Powers. The Dardanelles campaign, also known as the Gallipoli campaign constitutes one of the most "recounted episodes of the First World War" (Gilbert, 2000, p. xiii). The Anglo-French naval attack on the Dardanelles in March 1915, and the allied military landings in April on the Gallipoli Peninsula, followed by the fighting ended with the evacuation of the allied forces. The Gallipoli war lasted for eight and a half months and despite the heroic struggle on both sides and the Central Powers losing the battle the Ottoman Empire was dismantled. The Allies later returned to Gallipoli at the end of 1918 as the winners of the war.

From the British point of view, the victory at Dardanelles could have greatly reduced the threat to Egypt and the Suez Canal, eased the pressure on Russia, and possibly brought Italy, Bulgaria and Romania into the allied camp. Thus, the Allies believed that combined naval and military assault would enable them to achieve these goals. The defeat of the Ottomans in 1915, to quote Prior, "would have saved temporarily the lives that were lost in the Palestinian and Mesopotamian campaigns from 1916-1918. Had Turkey fallen in 1915 these troops would have been transferred to the western front" (Prior, 2010, p. 251; Mert, 2002). The Allied situation, already "cursed by the stalemate at the Western front and gloom on the eastern front", could have been changed with a victory at the Dardanelles, a place that marked a "turning point of Allied fortunes" (Gilbert, 2004, p. 33).

Moreover, the Turks having deployed 300,000 Turkish soldiers on the Gallipoli front made their position in Palestine and Iraq susceptible to attack by the Allied forces, thus indirectly enhanced British position there and ensured easier and quicker gains for British troops. This also helped the Russian military operations in the east.

Last but not least, the capacity and competency of "the Empire on which the sun never sets"- the phrase often used to describe the British Empire at the peak of its power-was brought under scrutiny with the belief that the Empire was a beatable power perhaps creating a way for those living under its dominions, colonies, 
protectorates and mandates to begin to challenge notions of British rule ${ }^{10}$.

As for the Turkish perspective, the Dardanelles campaign to some degree changed the course of history. Although the Ottomans had been defeated in the war, their victory in Gallipoli played a functional role in aiding the Russian revolution by cutting Russia from its Allies, thus depriving it of logistic support and vital supplies. It is often argued in the literature that had the Allies succeeded in passing through the Dardanelles, the Russian revolution may not have happened.

By engaging nearly half a million British and French troops in the Peninsula, keeping them away from the German front, it immensely eased the German position in Eastern Europe. The idea that the war would not have lasted as long and would have been over in 1916 had to be abandoned as result of the Ottoman victory that prolonged the war for another two years. It allowed the Turks to rebuild their confidence that was lost with their terrible defeat suffered in the Balkan wars.

Finally, perhaps the most significant outcome was the momentum that paved the way to the establishment of the Turkish Republic. The outcome of this momentous battle blocked the way to Istanbul and prolonged the war with the result of the occupation of Anatolia in 1918 which triggered the National Struggle to liberate the country. The reference point of all these was Çanakkale and the morale and impetus derived from it. Moreover, this campaign put Mustafa Kemal in the limelight as the hero of the day and it was followed by a series of both military and political victories ensuring his surname of Ataturk (father of the Turks) in the years to come.

\section{References}

Aksakal, M. (2008). The Ottoman road to war in 1914: The Ottoman Empire and the First World War. Cambridge: Cambridge University Press.

Bartlett, E. A. (2007). Bir İngiliz Savaş Muhabirinin Kaleminden Çanakkale Gerçeği. İstanbul: Yeditepe Yayınevi.

Bean, C. (1948). Gallipoli mission. Canberra: Australian War Memorial.

Beşikçi, M. (2014). Birinci Dünya Savaşında Osmanlı seferberliği. İstanbul: Türkiye İş Bankası Kültür Yayınları.

Coates, T. (2001). The World War One collection: Gallipoli and the early battles, 1914-15. London: The Stationary Office.

Demirci, S. (2014). Birinci Dünya Savaşında İngiliz Diplomasisi: İngiltere'nin Osmanlı Politikasını Anlama. In Ü. Özdağ (Ed.), 100. Yılında Birinci Dünya Savaşı (pp. 181-196). Ankara: Kripto Yayınları.

Erdemir, L., \& Güneş, İ. (Eds.). (2014). Çanakkale Cephesinde Bir Topçu Subayının Günlügü. Çanakkale: Çanakkale 18 Mart Üniversitesi Yayınları.

Erickson, E. J. (2008). Gallipoli and the Middle East 1914-1918: From the Dardanelles to Mesopotamia. London: Amber Book. Fewster, K., Başarın, V., \& Başarın, H. H. (2003). Gallipoli: The Turkish story. Crows Nest: Allen \& Unwin.

Gilbert, M. (2000). The straits of war: Gallipoli remembered. Stroud: Sutton Publishing.

Gilbert, M. (2004). Churchill and Gallipoli. In J. Macleod (Ed.), Gallipoli: Making history (pp. 15-16). London: Frank Cass.

Hartesveldt, F. R. V. (1997). The Dardanelles campaign, 1915: Historiography and annotated bibliography. London: Greenwood Press.

Hayhorntwaite, P. (1991). Gallipoli 1915: Frontal assault on Turkey. London: Osprey Publishing.

Ilgar, İ., \& Uğurlu, N. (Eds.). (2003). Esat Paşanın Çanakkale Savaşı Hatıraları. İstanbul: Örgün Yayınevi.

James, R. R. (1965). Gallipoli: Grand strategy. London: Pan Books Ltd.

Kannengiesse Pasha, H. (1928). The campaign in Galipoli. London: Hutchinson \& Co. Ltd.

Kearsey, A. (2006). Notes and comments on the Dardanelles campaign. Aldershot: Gale \& Polden Ltd.

Mert, H. (2002). Çanakkale Savaşlarının Askeri, Siyasi ve Sosyal Sonuçları. Retrieved from http://www.altayli.net/canakkale-savaslarinin-askeri-siyasi-ve-sosyal-sonuclari.html

Muhlman, C. (2006). Çanakkale Savaşı: Bir Alman Subayının Notları. Istanbul: Timaş Yayınları.

\footnotetext{
${ }^{10}$ As a matter of fact dominions rejected to give military support to Britain against the Turks in 1922 in the face of a possible armed conflict with Turkey just before Mudania Armistice was signed which led to the peace negotiations at Lausanne.
} 
Özdemir, B., \& Mutaf, A. (Eds.). (2012). Çanakkale Muharebatı: Cihan Harbinde Osmanlı Harekat-ı Tarihçesi. Ankara: Türk Tarih Kurumu.

Pomiankowiski, J. (1990). Osmanlı İmparatorluğunun Çöküşü. İstanbul: Kayıhan Yayınları.

Prior, R. (2010). Gallipoli: The end of the myth. New Heaven: Yale University Press.

Reynolds, M. A. (2011). Shattering empires: The clash and collapse of the Ottoman and Russian Empires 1908-1918. Cambridge: Cambridge University Press.

Rogen, E. (2015). The fall of the Ottomans. New York: Basic Books.

Sanders, L. V. (1999). Türkiye'de Beş Yıl. İstanbul: Yeni Gün Haber Ajansı Basın ve Yayıncılık A.Ş.

Shakland, P., \& Hunter, A. (1964). Dardanelles patrol. New York: Charles Scribner's Sons.

Shaw, S. J. (2006). The Ottoman Empire in World War (Vols. I-II). Ankara: Turk Tarih Kurumu.

Stone, N. (2010). Turkey: A short history. London: Thames and Hudson.

Trumpener, U. (1968). Germany and the Ottoman Empire 1914-1918. Princeton: Princeton University Press.

Trumpener, U. (1975). German officers in the Ottoman Empire, 1880-1918: Some comments on their backgrounds, functions and accomplishments. In J. L. Wallach (Ed.), Germany and the Middle East 1835-1939: International Symposium proceedings (pp. 30-44). Tel Aviv University.

Ulrichsen, K. C. (2014). The First World War in the Middle East. London: C. Hurst \& Co. Ltd.

Vaidis, T. A. (2005). Bir Yunanlı Gazeteci Gözüyle Atatürk. Publisher: Kum Saati. 